(c) Group of authors, 2021

UDC 616.366-003.7

DOI - https://doi.org/10.14300/mnnc.2021.16030

ISSN - 2073-8137

\title{
HELICOBACTER PYLORI AS A RISK FACTOR FOR THE DEVELOPMENT OF METABOLIC SYNDROME AND GALLSTONE DISEASE
}

\author{
Svistunov A. A. ${ }^{1}$, Osadchuk M. A. ${ }^{2}$, Mironova E. D. ${ }^{2}$, Vasil'eva I. N. ${ }^{2}$ \\ ${ }^{1}$ First Moscow State Medical University (Sechenov University), Russian Federation \\ 2 Institute of Clinical Medicine named after N. V. Sklifosovsky, Moscow, \\ Russian Federation
}

\section{HELICOBACTER PYLORI KAK ФAKTOP РИСКA РАЗВИТИЯ МЕТАБОАИЧЕСКОГО СИНАРОМА И ЖЕАЧНОКАМЕННОЙ БОАЕЗНИ}

\author{
А. А. Свистунов ${ }^{1}$, М. А. ОсаАчук ${ }^{2}$, Е. А. Миронова ${ }^{2}$, И. Н. Васильева ${ }^{2}$ \\ 1 Первый Московский госуАарственный меАицинский университет \\ им. И. М. Сеченова (Сеченовский Университет), Российская ФеАерация \\ 2 Институт кАинической МеАицины им. Н. В. СкАифосовского, Москва, \\ Российская Фелерация
}

To study the Helicobacter pylori ( $\mathrm{H}$. pylori) effect on gallstone disease development and metabolic syndrome (MetS) and its components, the main factors of biliary stone formation. The study included 143 patients with cholelithiasis, of which $88(61.5 \%)$ were infected with $\mathrm{H}$. pylori and 55 (38.5\%) were not. All subjects were assessed for MetS and its components severity. A high prevalence of metabolic disorder and MetS was revealed in patients with $\mathrm{H}$. pylori. The results obtained suggest that $\mathrm{H}$. pylori promotes gallbladder calculi development by affecting patients` metabolic profile.

Keywords: gallstone disease, Helicobacter pylori, metabolic syndrome

Изучено влияние Helicobacter pylori (H. pylori) на развитие желчнокаменной болезни (ЖКБ), а также метаболического синдрома (МС) и его компонентов - основных факторов, влияющих на формирование желчных конкрементов. В исследование было включено 143 пациента с ЖКБ, из которых 88 (61,5 \%) инфицированы H. pylori и 55 (38,5 \%) не инфицированы. Среди всех испытуемых была проведена оценка выраженности МС и его компонентов. В результате была выявлена большая распространенность метаболических нарушений и MC у пациентов с H. pylori. Tаким образом, полученные результаты дают основание полагать, что Н. pylori способствует развитию конкрементов в желчном пузыре путем воздействия на метаболический профиль пациентов.

Ключевые слова: желчнокаменная болезнь, Helicobacter pylori, метаболический синдром

For citation: Svistunov A. A., Osadchuk M. A., Mironova E. D., Vasil'eva I. N. HELICOBACTER PYLORI AS A RISK FACTOR FOR THE DEVELOPMENT OF METABOLIC SYNDROME AND GALLSTONE DISEASE. Medical News of North Caucasus. 2021;16(2):135-139. DOI - https://doi.org/10.14300/mnnc.2021.16030

Для цитирования: Свистунов А. А., Осадчук М. А., Миронова Е. Д., Васильева И. H. HELICOBACTER PYLORI KAK ФАКТОР РИСКА РАЗВИТИЯ МЕТАБОЛИЧЕСКОГО СИНДРОМА И ЖЕЛЧНОКАМЕННОЙ БОЛЕЗНИ. МеДИЦИНСКИЙ ВЕСТник Северного Кавказа. 2021;16(2):135-139. DOI - https://doi.org/10.14300/mnnc.2021.16030

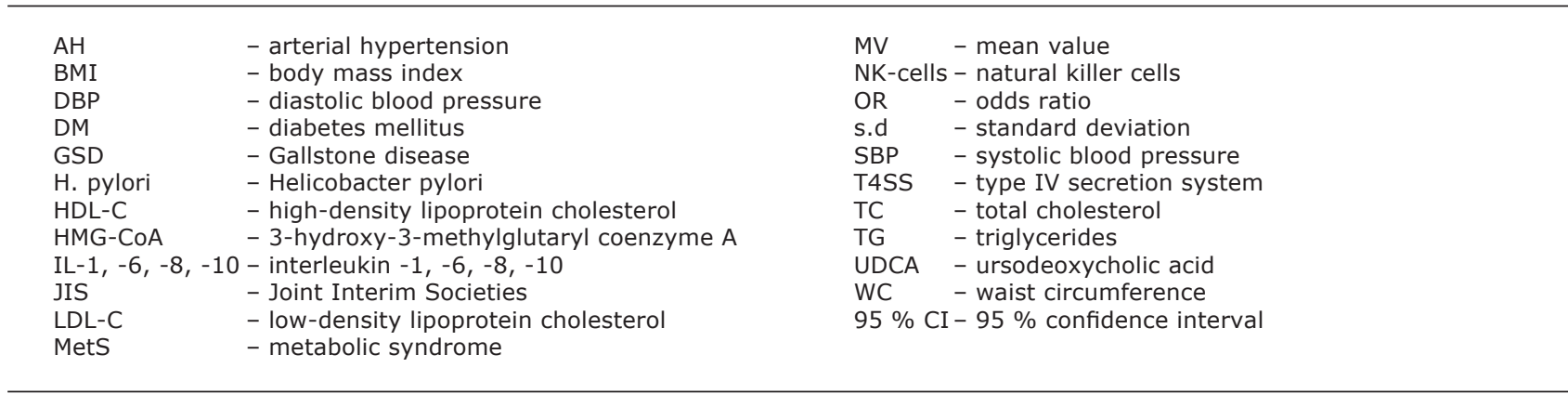


$\mathrm{G}$ allstone disease (GSD) is one of the most common gastrointestinal tract pathologies, often resulting in complications in cholecystitis, pancreatitis, and secondary infections. It is also associated with digestive system cancer. According to epidemiological data, gall bladder calculi are found in 10-20\% of developed countries' inhabitants [1]. At present, risk factors for cholelithiasis development are well studied. The main ones determining the disease formation and progression are metabolic syndrome (MetS) and its components, which include overweight, diabetes mellitus (DM), arterial hypertension ( $\mathrm{AH})$, and dyslipidemia. Recently, however, researchers have been interested in studying the Helicobacter pylori ( $\mathrm{H}$. pylori) role in developing GSD and metabolic disorders.

$\mathrm{H}$. pylori is a gram-negative microaerophilic spiral bacterium with flagella. It colonizes the stomach mucous membrane in half of the world's population, exposing them to a high risk of gastritis, peptic ulcer, and gastric adenocarcinoma. Over the past few years, numerous studies have confirmed the linkage between cholelithiasis and $\mathrm{H}$. pylori infection $[2,3]$. This microorganism is also found in tissue samples of the bile, calculi, gallbladder, and liver. $H$. pylori virulence factors include vacAs 1 , iceA1, babA2, cagA, and cagE genes, which play different roles in GSD pathogenesis [4]. Researchers have found that vacAs 1 , iceA1, and babA2 are the most predominant genotypes in groups of patients with cholangiocarcinoma and GSD. Both cagA and cagE can be potential markers for predicting hepatobiliary disease severity [5]. A link between $\mathrm{H}$. pylori infection and metabolic disorders has also been proven [6]. $\mathrm{H}$. pylori eradication leads to a decrease in metabolic changes associated with a decrease in waist circumference (WC), glycemic and lipid profiles [2, 3]. It can be assumed that GSD high prevalence among the population can be linked with $\mathrm{H}$. pylori infection rapid growth and its effect on the metabolic profile. In this regard, the study of this microorganism's role in MetS development in GSD patients is fundamental.

Material and Methods. A total of 143 patients with GSD aged 40 to 65 years were examined, with 110 (77\%) women and 33 (23\%) men among them. The participant's average age was $55.2 \pm 7.51$ years. Among 143 patients with cholelithiasis, $\mathrm{H}$. pylori infection was detected in $88(61.5 \%)$. All patients gave written informed consent to participate and were examined following the World Health Organization Helsinki Declaration principles and bioethics rules. The work took into account the following data: anamnestic (the presence of $\mathrm{AH}$ and $\mathrm{DM}$ ), anthropometric (height, body mass, body mass index (BMI), WC) and biochemical (total cholesterol (TC), high-density lipoprotein cholesterol (HDL-C), low-density lipoprotein cholesterol (LDL-C), triglycerides (TG), glucose). In addition, MS verification was carried out based on the JIS criteria (Table 1).

Gallbladder stones were detected using ultrasound of the abdominal organs. The material for a cytological study to detect $\mathrm{H}$. pylori infection was Romanovsky-Giemsa $76,1 \%$ *

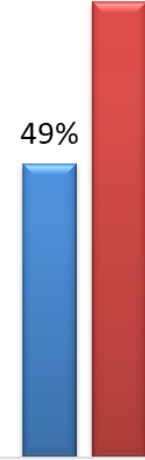

stained smear-prints of biopsy samples obtained by esophagogastroduodenoscopy from mucous membrane sections of the stomach antrum.

Statistical analysis was carried out per the goal. The Kolmogorov-Smirnov test was used to assess the distribution normality of variables. $\mathrm{MV} \pm$ s.d and $95 \% \mathrm{Cl}$ were calculated for numerical variables. The U-MannWhitney test was applied, taking into account sample normal distribution. Comparison of the two groups' qualitative data was carried out using contingency tables of Fisher's exact test. The SPSS 22.0 program (SPSS Inc, USA) for Windows (Microsoft Corporation, USA) was used for statistical analysis, while $p<0.05$ was considered statistically significant.

MS JIS, 2009 Criteria

Table 1

\begin{tabular}{|c|c|c|}
\hline 1 & WC>94 cm (men), >80 cm (women) & \multirow{5}{*}{$\begin{array}{l}\text { Any } 3 \text { of the } \\
\text { listed }\end{array}$} \\
\hline 2 & $\begin{array}{l}\text { Systolic blood pressure (SBP) }>130 \\
\mathrm{~mm} \mathrm{Hg} \text { and diastolic blood pressure } \\
(\mathrm{DBP})>85 \mathrm{~mm} \mathrm{Hg}{ }^{*}\end{array}$ & \\
\hline 3 & $\mathrm{TG}>1.7 \mathrm{mmol} / \mathrm{L} * *$ & \\
\hline 4 & $\begin{array}{l}\mathrm{HDL}-\mathrm{C}<1.0 \mathrm{mmol} / \mathrm{L} \quad \text { (men), }<1.3 \\
\mathrm{mmol} / \mathrm{L} \text { (women)** }\end{array}$ & \\
\hline 5 & Fasting glucose $>5.6 \mathrm{mmol} / \mathrm{L} * * *$ & \\
\hline
\end{tabular}

* Or for previously diagnosed AH treatment.

** Or for this disorder-specific treatment.

*** Or previously diagnosed type 2 DM.

Results and Discussion. A prevalence assessment of metabolic disorder components was made in conformity with the research goal. It was found that according to JIS-2009 criteria (Joint Interim Societies, 2009), GSD patients infected with $H$. pylori are more likely to have all MetS components compared with GSD patients without $\mathrm{H}$. pylori infection (Fig.). The most pronounced differences were observed in WC criteria $>94$ $\mathrm{cm}$ in men, and $>80 \mathrm{~cm}$ in women $(76.1 \%$ in $\mathrm{H}$. pyloripositive cases versus $49 \%$ in $\mathrm{H}$. pylori-negative ones, $\mathrm{p}<0.05), \mathrm{TG}>1,7 \mathrm{mmol} / \mathrm{L}(56.8 \%$ in $\mathrm{H}$. pylori-positive cases versus $38.1 \%$ in $\mathrm{H}$. pylori-negative ones, $\mathrm{p}<0.05$ ) and $\mathrm{HDL}-\mathrm{C}<1.0 \mathrm{mmol} / \mathrm{L}$ (men), $<1.3 \mathrm{mmol} / \mathrm{L}$ (women) (30.6\% in $\mathrm{H}$. pylori-positive cases versus $10.9 \%$ in

H. pilory-negative $(n=55)$ H. pilory-positive $(n=88)$ $65,9 \%$

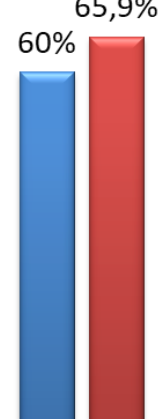
$56,8 \%$ *
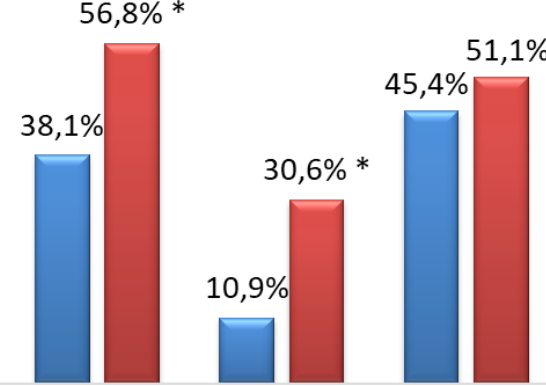

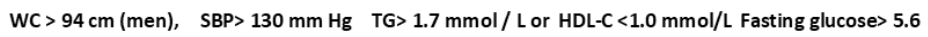
$>80 \mathrm{~cm}$ (women) and DBP> $85 \mathrm{~mm}$ specific treatment (men), $<1.3 \mathrm{mmol} / \mathrm{L} \mathrm{mmol} / \mathrm{L}$ or $\mathrm{Hg}$ or for treatment for this disorder (women) or specific previously $\begin{gathered}\text { g or for treatment } \\ \text { of previously }\end{gathered}$
for this disorder
treatment for this diagnosed type 2 diagnosed hypertension disorder DM

Fig. Metabolic disorder prevalence, based on the JIS-2009 criteria in individuals with GSD depending on $\mathrm{H}$. pylori infection

$\left({ }^{*}-\right.$ Fisher's exact test $\left.p<0.05\right)$ 
$\mathrm{H}$. pylori-negative ones, $\mathrm{p}<0.05)$. A patient with three or more MetS components, according to JIS-2009 criteria, was recognized as having MetS. Thus, the study results demonstrate a higher MetS prevalence in GSD patients with $\mathrm{H}$. pylori infection compared with GSD individuals without it $(62.5 \%$ in $\mathrm{H}$. pylori-positive versus $40 \%$ in $\mathrm{H}$. pylori-negative, $\mathrm{p}<0.05$ )

We assessed the average rate of anthropometric measurements and blood serum chemistry (Table 2). It was found that individuals with $\mathrm{H}$. pylori infection are more prone to obesity compared to uninfected ones, as they have higher average weight, BMI, and WC rates. Also, these patients had more pronounced lipid metabolism disorders. They often had high TC, LDL-C, and TG levels and lower HDL-C levels compared with uninfected patients. Also, among GSD patients infected with $\mathrm{H}$. pylori, more pronounced carbohydrate metabolism disorders compared with $\mathrm{H}$. pylori-negative patients. With the help of U-Mann-Whitney test, it was found that in GSD patients $\mathrm{H}$. pylori infection statistically significantly affects weight gain $(U=1334.5 ; Z=-4.506 ; p=0.001)$, $B M I \quad(U=1233.5$; $Z=-4.924 ; p=0.001), W C(U=1333.5 ; Z=-4.511 ; p=0.001)$, an increase in plasma levels of $T G(U=1823 ; Z=-2.477$; $p=0.013)$ and a decrease in the level of HDL-C $(U=1791$; $Z=-2.610 ; p=0.009)$.

Table 2

Results of anthropometric measurements and blood counts in GSD patients depending on $\mathrm{H}$. pylori infection

\begin{tabular}{|c|c|c|c|c|c|c|}
\hline \multicolumn{2}{|c|}{ Indicator } & $\begin{array}{c}\text { Mean value } \\
\text { (MV)士- } \\
\text { standard } \\
\text { deviation } \\
\text { (s.d) }\end{array}$ & $\begin{array}{l}95 \% \mathrm{Cl} \\
\text { (confi- } \\
\text { dence } \\
\text { interval) }\end{array}$ & $\begin{array}{c}\text { Mann- } \\
\text { Whit- } \\
\text { ney } \\
\text { U-test }\end{array}$ & Z & $\mathrm{p}$ \\
\hline \multirow[t]{2}{*}{ Age } & 1 & $54.6 \pm 7.2$ & $52.6-56.6$ & \multirow{2}{*}{2186.5} & \multirow{2}{*}{-0.971} & \multirow{2}{*}{0.332} \\
\hline & 2 & $55.6 \pm 7.6$ & $54-57.2$ & & & \\
\hline \multirow[t]{2}{*}{ Weight } & 1 & $69.1 \pm 17.7$ & $64.3-73.9$ & \multirow{2}{*}{1334.5} & \multirow{2}{*}{-4.506} & \multirow{2}{*}{0.001} \\
\hline & 2 & $81.9 \pm 17$ & $78.3-85.5$ & & & \\
\hline \multirow[t]{2}{*}{ BMI } & 1 & $25.1 \pm 5.5$ & $23.6-26.6$ & \multirow{2}{*}{1233.5} & \multirow{2}{*}{-4.924} & \multirow{2}{*}{0.001} \\
\hline & 2 & $30.4 \pm 5.9$ & $29.1-31.7$ & & & \\
\hline \multirow[t]{2}{*}{ WC } & 1 & $82 \pm 11.5$ & $78.9-85.1$ & \multirow{2}{*}{1333.5} & \multirow{2}{*}{-4.511} & \multirow{2}{*}{0.001} \\
\hline & 2 & $90 \pm 8.7$ & $88.2-91.9$ & & & \\
\hline \multirow[t]{2}{*}{ TC } & 1 & $5.5 \pm 1.1$ & $5.2-5.8$ & \multirow{2}{*}{2204.5} & \multirow{2}{*}{-0.894} & \multirow{2}{*}{0.371} \\
\hline & 2 & $5.7 \pm 0.9$ & $5.5-5.9$ & & & \\
\hline \multirow[t]{2}{*}{ LDL-C } & 1 & $3.2 \pm 0.9$ & $2.9-3.4$ & \multirow{2}{*}{2133} & \multirow{2}{*}{-1.191} & \multirow{2}{*}{0.234} \\
\hline & 2 & $3.4 \pm 0.9$ & $3.2-3.6$ & & & \\
\hline \multirow[t]{2}{*}{ HDL-C } & 1 & $1.4 \pm 0.3$ & $1.3-1.5$ & \multirow{2}{*}{1791} & \multirow{2}{*}{-2.610} & \multirow{2}{*}{0.009} \\
\hline & 2 & $1.2 \pm 0.3$ & $1.1-1.3$ & & & \\
\hline \multirow[t]{2}{*}{ TG } & 1 & $1.5 \pm 0.5$ & $1.4-1.7$ & \multirow{2}{*}{1823} & \multirow{2}{*}{-2.477} & \multirow{2}{*}{0.013} \\
\hline & 2 & $2 \pm 0.9$ & $1.8-2.2$ & & & \\
\hline \multirow{2}{*}{$\begin{array}{l}\text { Glu- } \\
\text { cose }\end{array}$} & 1 & $5.5 \pm 0.7$ & $5.3-5.7$ & \multirow{2}{*}{2094} & \multirow{2}{*}{-1.353} & \\
\hline & 2 & $5.8 \pm 1.2$ & $5.5-6.1$ & & & 0.170 \\
\hline
\end{tabular}

Note: $1-\mathrm{H}$. pylori-negative $(\mathrm{n}=55) ; 2-\mathrm{H}$. pylori-positive $(n=88)$.

Data analysis concludes that GSD patients with MetS are highly infected with $\mathrm{H}$. pylori $(61.5 \%$ versus $38.5 \%)$. In their study, S. B. Pradhan et al. wrote about a total of
$76.66 \%$ of patients with cholelithiasis who were infected with $\mathrm{H}$. pylori [7]. A meta-analysis by D. Zhou et al. found a trend towards higher $\mathrm{H}$. pylori infection among GSD patients than in control groups [3]. Another 2018 meta-analysis, which included 18 studies, found that $\mathrm{H}$. pylori infection was closely connected with an increased risk of developing cholelithiasis [2]. It is reported that $H$. pylori has an effect on the entire hepatobiliary system since several researchers have managed to obtain the $H$. pylori bacterium from bile, calculi, and tissue samples of the gallbladder and liver in patients with GSD.

Gallstones are known to be a reservoir for bacteria. At the same time, mucus production facilitates their adhesion, and $\beta$-glucuronidase and phospholipase form a surface for colonization. In turn, gallstones enriched with bacteria exacerbate disease severity, depending on the bacterial composition. At the same time, dense microorganism clusters in biofilm attached to the mucous membrane surface and calculi are more resistant to antibacterial drugs [8]. By modifying the lipopolysaccharide lipid component, H. pylori evade recognition by the host immune system. Proteomes can trigger another process of immune intervention on biofilm containing $\mathrm{H}$. pylori.

Biofilm is a reservoir for a variety of microorganisms, in particular for $\mathrm{H}$. pylori. It promotes genetic exchange between them. Amplification of antibiotic-resistant genes spreads in biofilms due to horizontal transfer of genes, which are integrative to conjugative elements [9]. In addition, stressful conditions can contribute to mutations and the emergence of antibiotic-resistant strains. In vitro studies have shown that the cagA and T4SS genes are involved in biofilm formation with $\mathrm{H}$. pylori [10]. It is important to note that $\mathrm{H}$. pylori CagA is an oncoprotein produced in the bacterial cytosol and then penetrates the host cell cytosol using a type IV cell secretion system (T4SS). CagA regulates autophagy, reduces epithelial cell apoptosis by interacting with tumor suppressors such as p53 [11], stimulates an inflammatory response via the c-Met-PI3K/Akt-mTOR signaling pathway, [12] and is a marker for predicting hepatobiliary disease severity [5]. An interesting fact is that $\mathrm{H}$. pylori is a cholesterol auxotroph since it extracts lipids from host membranes to incorporate it into its outer shell using the cholesterol- $\alpha$-glucosyltransferase enzyme. Cholesterol glucosylation and extraction from host cells lead to lipid raft destruction and/or a change in the membrane structure associated with immunity evasion and bacteria resistant to treatment [13]. Besides, there is a distinct shift in the distal intestinal tract microbiota resulting from $\mathrm{H}$. pylori infection development. Undoubtedly, the imbalance between the gastrointestinal tract microbiota and the host contributes to immune, inflammatory, and metabolic disorder development [14].

We found a positive relationship between $\mathrm{H}$. pylori and MetS in GSD patients for whom both MetS and its components were much more common (Fig., Table 2). Many researchers have confirmed the link between $\mathrm{H}$. pylori carriage and MetS. So, a meta-analysis, which included 18 studies with 27,544 participants, demonstrated $\mathrm{H}$. pylori and MetS correlation (odds ratio $(O R)=1.34$, $95 \%$ $\mathrm{Cl}=1.17-1.53, \mathrm{p}<0.01)$ and significant difference in glucose, HDL-C, BMI, TG and blood pressure between infected and uninfected groups of patients [6].

$\mathrm{H}$. pylori colonising the crypts and gastric mucosa inevitably leads to chronic gastritis with mild chronic inflammation. Although $\mathrm{H}$. pylori does not enter the bloodstream, the Infection's long-term effects are induced by circulating cytokines, acute phase proteins, and other mediators. In addition, $\mathrm{H}$. pylori virulence factors induce inflammatory proteins and cytokines such as $\mathrm{C}$-reactive protein, tumor 
necrosis factor- $\alpha$, interleukins (IL-1, IL-6, IL-8, IL-10) eicosanoids. They can act remotely from $\mathrm{H}$. pylori's natural habitat [15] and participate in the pathogenesis of MetS, its components, and cholelithiasis.

The statistically significant relationship between $\mathrm{H}$. pylori and obesity that we found correlates with other researchers results [6]. A study by Li-Wei Chen et al., which included 2604 subjects, showed $\mathrm{H}$. pylori-positive effect on obesity development [16]. So, H. pylori affects producing ghrelin and leptin, which are involved in metabolic and energy balance regulation and are responsible for hunger and satiety formation. Studies conducted have shown a decrease in leptin and ghrelin serum levels in patients infected with $\mathrm{H}$. pylori. Leptin forms a feeling of fullness and suppresses food intake, and its decrease is associated with excessive food consumption and obesity degree. Moreover, a decrease in ghrelin concentration in blood plasma is a physiological adaptation to a positive energy balance associated with excess body weight. CagA protein is also involved in the formation of obesity in individuals with $\mathrm{H}$. pylori infection. Thus, according to one of the studies, in CagA-positive patients infected with $\mathrm{H}$. pylori, BMI was higher than in CagA-negative ones $[1.13+/-0.26 \mathrm{~mm}$ vs $0.97+/-0.15 \mathrm{~mm}$; univariate analysis, $\mathrm{p}=0.0001$; multivariate analysis: $\mathrm{OR}=2.36$; $95 \% \mathrm{Cl}=1.57-$ 3.54; $p=0.0001$ ] [17]. Also, in overweight individuals, changes in innate and adaptive immunity such as slowing monocyte and macrophage maturation and decreased polymorphic-nuclear bactericidal ability are observed. This undoubtedly increases $\mathrm{H}$. pylori colonising the gastric mucosa. In obese patients, natural killer cells (NK) metabolic reprogramming that violates immunological surveillance is detected. Intestinal microbiota changes caused by $\mathrm{H}$. pylori also contribute to patient overweight formation.

Our data indicate an increase in the frequency of DM and elevated glucose levels in patients with $\mathrm{H}$. pylori infection. Similar results were recorded in other studies [6]. Interestingly, patients with $\mathrm{H}$. pylori infection, especially young people, have defects in insulin secretion associated with an increase in gastrin concentration and a decrease in serum somatostatin levels. This leads to a decrease in insulin levels, followed by carbohydrate tolerance formation and DM development. It is worth noting that $\mathrm{H}$. pylori infection is closely linked with a decrease in the pepsinogen I/pepsinogen II ratio associated with serum glucose levels. DM also causes cellular and humoral immunity violation, which increases vulnerability to $\mathrm{H}$. pylori infection. An imbalance in carbohydrate metabolism inhibits gastrointestinal tract motility, which results in a delay of infected evacuation from the stomach and a decrease in hydrochloric acid secretion. This, in turn, increases its colonization by pathogenic bacteria. Shifts in the intestinal microbiota associated with $\mathrm{H}$. pylori infection correlate with changes in carbohydrate metabolism [14]. With microbial dysbiosis, there is an increase in the harmful metabolite number and a change in the bile acid composition, which comes from carbohydrate and protein fermentation. As a result, insulin resistance pathways are activated and initiate obesity, diabetes, and atherosclerosis [14].

Epidemiological studies have shown that $\mathrm{H}$. pylori infection is associated with cardiovascular diseases and their risk factors. Z. Wan et al. conducted a cross-sectional study, which included 5,246 adult participants, and found that $\mathrm{H}$. pylori infection correlated with $\mathrm{AH}$ prevalence [18]. Also, there is evidence that patients with $\mathrm{H}$. pylori infection are prone to atherosclerotic vascular lesions caused by changes in the lipid profile.
Among our study subjects, patients infected with $\mathrm{H}$. pylori had severe dyslipidemia compared with uninfected ones. We have established a statistically significant relationship between $\mathrm{H}$. pylori infection, decreased $\mathrm{HDL}$, and increased serum TG. Similar results were obtained by other authors [6]. A. Hoffmeister et al. also recorded lower HDL-C and WC values in infected patients $(p=0.005)$ [19]. $\mathrm{T}$. Gunji et al., in addition to the positive association between $\mathrm{H}$. pylori and low HDL-C values $(p<0.001)$, found a link with LDL-C $(p=0.005)$ [20] A. Laurila et al. [21] reported a significant TG increase in $\mathrm{H}$. pylori-positive patients [10]. These changes in lipid homeostasis were significant even after adjustment of the socioeconomic status, body weight, age, and DM [21].

$H$. pylori infection affects cytokine production, including IL-6 release [15]. Exciting data are presented in a study by Pohjanen et al., which compared serum lipids concentration in $\mathrm{H}$. pylori-positive and negative patients and controlled IL-6-174 polymorphism. As a result, data were obtained proving that $\mathrm{H}$. pylori infection is more associated with low HDL levels in the serum of patients with the IL- $6-174$ genotype. This suggests that the association between $\mathrm{H}$. pylori infection and serum HDL can be transmitted through IL-6 [22]. Thus, these immune system reactions provoke changes in lipid metabolism and even contribute to coronary heart disease development. In addition, between the reduced pepsinogen I / pepsinogen II ratio resulting from $\mathrm{H}$. pylori infection there is a linear relationship with TG $(P<0.05), \mathrm{HDL}-\mathrm{C}(\mathrm{P}<0.01)$, the TG/HDL ratio $(p<0.05)$, and an increase in the lipid accumulation product index [23].

Successful $H$. pylori eradication therapy has a beneficial effect on metabolic processes, improving the lipid profile, decreasing insulin resistance, blood pressure, and contributing to a decrease in the pro-inflammatory cytokine level. $\mathrm{H}$. pylori has mechanisms of protection against host immunity and antibiotic therapy, which forces researchers worldwide to seek new treatments for the Infection. Due to a strong connection between cholelithiasis, $\mathrm{H}$. pylori, and metabolic disorders. Some scientists are considering GSD treatment with ursodeoxycholic acid (UDCA) combined with statins: 3-hydroxy-3-methylglutaryl coenzyme A (HMG$\mathrm{COA})$ reductase inhibitors. This combination normalizes lipid profile indices, increases bile lithogenicity, prevents cholesterol gallstone formation and promotes stone lysis [24]. At the same time, statins have antibacterial activity and act synergistically with antibiotics. Statins reduce $\mathrm{H}$. pylori infection risk by reducing the macrophage infection burden. Due to cellular cholesterol depletion under the influence of statins, CagA-induced damage is attenuated [25] and autophagy is enhanced, which undoubtedly has a beneficial effect on immune defense against pathogens.

Thus, in our study, the antibacterial eradication therapy effect was higher in the group of patients taking rosuvastatin compared with those not taking it (95\% versus $80 \%$ ), which proves the additive, adjuvant effect of rosuvastatin on $\mathrm{H}$. pylori eradication [24]. Therefore, the above data show the relevance of UDCA combination with statins together with antibacterial eradication therapy in patients with GSD and $\mathrm{H}$. pylori.

Conclusions. Thus, the results obtained suggest that $\mathrm{H}$. pylori promotes gallbladder calculi development by affecting the patients' metabolic profile, acting as a GSD trigger factor. In this regard, a complex of preventive measures, including $\mathrm{H}$. pylori eradication, can help reduce the incidence of GSD and GSD-associated diseases of internal organs.

Disclosures: The authors declare no conflict of interest 


\section{References}

1. Rodriguez S., Gaunt T. R., Guo Y., Zheng J., Barnes M. R. [et al.] Lipids, obesity and gallbladder disease in women: Insights from genetic studies using the cardiovascular gene-centric 50K SNP array. European journal of human genetics: EJHG. 2015;24:106-112. https://doi.org/10.1038/ejhg.2015.63

2. Cen L., Pan J., Zhou B., Yu C., Li Y. [et al.] Helicobacter Pylori infection of the gallbladder and the risk of chronic cholecystitis and cholelithiasis: A systematic review and meta-analysis. Helicobacter. 2018;23(1). https://doi.org/10.1111/hel.12457

3. Zhou D., Zhang Y., Gong W., Mohamed S. O., Ogbomo H. [et al.] Are Helicobacter pylori and other Helicobacter species infection associated with human biliary lithiasis? A meta-analysis. PLoS One. 2011;6(11):e27390. https://doi.org/10.1371/journal.pone.0027390

4. Chang W.-L., Yeh Y.-C., Sheu B.-S. The impacts of H. pylori virulence factors on the development of gastroduodenal diseases. J. Biomed. Sci. 2018;25. https://doi.org/10.1186/s12929-018-0466-9

5. Jeyamani L., Jayarajan J., Leelakrishnan V., Swaminathan M. CagA and VacA genes of Helicobacter pylori and their clinical relevance. Indian J. Pathol. Microbiol. 2018;61(1):66-69. https://doi.org/10.4103/IJPM.IJPM 23417

6. Upala S., Jaruvongvanich $\bar{V}$., ${ }^{\text {Riangwiwat } T \text {., }}$ Jaruvongvanich S., Sanguankeo A. Association between Helicobacter pylori infection and metabolic syndrome: a systematic review and meta-analysis. J. Dig. Dis. 2016;17(7):433-440.

https://doi.org/10.1111/1751-2980.12367

7. Pradhan S. B. Study of Helicobacter hepaticus in gallbladders with cholelithiasis and its sensitivity pattern. Kathmandu Univ. Med. J. (KUMJ). 2009;7:125-128. https://doi.org/10.3126/kumj.v7i2.2704

8. Yonezawa $\mathrm{H}$. Osaki $\mathrm{T}$, Hojo $\mathrm{F}$, Kamiya $\mathrm{S}$. Effect of Helicobacter pylori biofilm formation on susceptibility to amoxicillin, metronidazole and clarithromycin. Microb. Pathog. 2019;132:100-108. https://doi.org/10.1016/j.micpath.2019.04.030

9. Madsen J. S., Burmølle M., Hansen L. H., Sørensen S. J. The interconnection between biofilm formation and horizontal gene transfer. FEMS Immunol. Med. Microbiol. 2012;65(2):183-195 https://doi.org/10.1111/j.1574-695X.2012.00960.x

10. Wong E. H., Ng C. G., Chua E. G., Tay A. C., Peters F. [et al.] Comparative Genomics Revealed Multiple Helicobacter pylori Genes Associated with Biofilm Formation In Vitro. PLoS One. 2016;11(11):e0166835. https://doi.org/10.1371/journal.pone.0166835

11. Wei J., Noto J. M., Zaika E., Romero-Gallo J., Piazuelo M. B. [et al.] Bacterial CagA protein induces degradation of p53 protein in a p14ARF-dependent manner. Gut. 2015;64(7):1040-1048. https://doi.org/10.1136/gutjnl-2014-307295

12. Li N., Tang B., Jia Y. P., Zhu P., Zhuang Y. [et al.] Helicobacter pylori CagA Protein Negatively Regulates Autophagy and Promotes Inflammatory Response via c-Met-PI3K/Akt-mTOR Signaling Pathway. Front. Cell. Infect. Microbiol. 2017;7:417. https://doi.org/10.3389/fcimb.2017.00417
13. Wunder C., Churin Y., Winau F., Warnecke D., Vieth M. [et al.] Cholesterol glucosylation promotes immune evasion by Helicobacter pylori. Nat. Med. 2006;12(9):1030-1038. https://doi.org/10.1038/nm1480

14. Altuntas Y., Batman A. Microbiota and metabolic syndrome. Turk Kardiyol. Dern. Ars. 2017:45(3):286-296. https://doi.org/10.5543/tkda.2016.72461

15. Tsai H.-F., Hsu P.-N. Interplay between Helicobacter pylori and immune cells in immune pathogenesis of gastric inflammation and mucosal pathology. Cell. Mol. Immunol. 2010;7(4):255-259. https://doi.org/10.1038/cmi.2010.2

16. Chen L.-W., Kuo S.-F., Chen C.-H., Chien C.-H., Lin C.L. [et al.] A community-based study on the association between Helicobacter pylori Infection and obesity. Sci. Rep. 2018;8(1):10746. https://doi.org/10.1038/s41598-018-28792-1

17. Diomedi M., Pietroiusti A., Silvestrini M., Rizzato B., Cupini L. M. [et al.] CagA-positive Helicobacter pylori strains may influence the natural history of atherosclerotic stroke. Neurology. 2004;63(5):800-804.

https://doi.org/10.1212/01.wnl.0000138025.82419.80

18. Wan Z., Hu L., Hu M., Lei X., Huang Y. [et al.] Helicobacter pylori infection and prevalence of high blood pressure among Chinese adults. J. Hum. Hypertens. 2018:32(2):158164. https://doi.org/10.1038/s41371-017-0028-8

19. Hoffmeister A., Rothenbacher D., Bode G., Persson K., März W. [et al.] Current Infection with Helicobacter pylori, but not seropositivity to Chlamydia pneumoniae or cytomegalovirus, is associated with an atherogenic modified lipid profile. Arterioscler. Thromb. Vasc. Biol. 2001;21(3):427-432. https://doi.org/10.1161/01.atv.21.3.427

20. Gunji T., Matsuhashi N., Sato H., Fujibayashi K., Okumura M. [et al.] Helicobacter pylori infection is significantly associated with metabolic syndrome in the Japanese population. Am. J. Gastroenterol. 2008:103(12):30053010. https://doi.org/10.1111/j.1572-0241.2008.02151.x

21. Laurila A., Bloigu A., Näyhä S., Hassi J., Leinonen M. [et al.] Association of Helicobacter pylori infection with elevated serum lipids. Atherosclerosis. 1999;142(1):207210. https://doi.org/10.1016/s0021-9150(98)00194-4

22. Pohjanen V.-M., Koivurova O.-P., Niemelä S. E., Karttunen R. A. [et al.] Role of Helicobacter pylori and interleukin 6-174 gene polymorphism in dyslipidemia: a case-control study. BMJ Open. 2016;6(1):e009987. https://doi.org/10.1136/bmjopen-2015-009987

23. Bahadoran Z., Mirmiran P., Zarif-Yeaganeh M., Zojaji H. Azizi F. Helicobacter pylori Stool Antigen Levels and Serological Biomarkers of Gastric Inflammation are Associated with Cardio-Metabolic Risk Factors in Type 2 Diabetic Patients. Endocrinol. Metab. (Seoul). $2015 ; 30(3): 280-287$

https://doi.org/10.3803/EnM.2015.30.3.280

24. Osadchuk M. A., Mironova E. D., Vasileva, I. N Korzhenkov N. P., Achkasov E. E. [et al.] Oral medical dissolution of gallstones in patients with gallstone disease. Pren. Méd. Argent. 2019:1:34-40.

25. Lai C. H., Chang Y. C., Du S. Y., Wang H. J., Kuo C. H. [et al.] Cholesterol depletion reduces Helicobacter pylori CagA translocation and CagA-induced responses in AGS cells. Infect. Immun 2008:76(7):3293-3303. https://doi.org/10.1128/IAl.00365-08

\section{About authors:}

Svistunov Andrej Alexeyevich, MD, PhD, DSc, Professor, First Vice-Rector; e-mail:6229808@mail.ru; https://orcid.org/0000-0003-1592-5703

Osadchuk Mikhail Alexeyevich, MD, PhD, DSc, Professor, Head of the Department of polyclinic therapy; tel.: +79160712626; e-mail: osadchuk.mikhail@yandex.ru; https://orcid.org/0000-0003-0485-6802

Mironova Ekaterina Dmitrievna, Applicant of the Department of polyclinic therapy; tel.: +79152094094; e-mail: yek.mironova1995@yandex.ru; https://orcid.org/0000-0003-3268-2408

Vasil'eva Inna Nikolaevna, MD, Associate Professor, Associate Professor of the Department of polyclinic therapy tel.: +79851999214; e-mail: inniva77@mail.ru; https://orcid.org/0000-0001-8335-1380 